\title{
DIE KAIROS-DOKUMENT - TEOLOGIE OF IDEOLOGIE?
}

\author{
Prof. V. E. d'Assonville.
}

"Die politieke krisis in Suid-Afrika vandag, is die KAIROS of die oomblik van waarheid, nie net vir apartheid nie maar ook vir die Kerk. 'n KAIROS is ' $n$ kritieke en beslissende moment, 'n tyd van genade en geleentheid, 'n uitdaging tot beslissing en optrede". So sê die 156 ondertekenaars self")'.

Kairos is ' $n$ baie belangrike Griekse woord in die Nuwe Testament, die "beslissende moment" vir Jesus en die gelowiges om die regte besluit volgens God se wil te neem ${ }^{2}$ ).

Radikaal staan dit op die titelbladsy: "Uitdaging aan die Kerk". Die geskrif bied homself aan as "'n Teologiese Kommentaar op die Politieke Krisis in Suid-Afrika"3).

Die groot vraag is: Het ons hier met ieologie te doen?

Die woord teologie kom van twee Griekse woorde "Theos" en "logos" letterlik "God" en "woord, leer". In kort kan ons sê dat dit die kennis oor God is ${ }^{4}$ ).

Hieraan sal ons nou die Kairos-dokument moet toets: Of dit vir ons die kennis oor God volgens die Bybel, die Heilige Skrif gee.

\section{Organisasie agter hierdie dokument}

Uit 'n groot verskeidenheid literatuur in die vorm van panflette, kerklike nuusbriewe, brosjures, koerantberigte ens. kan ons die volgende kort oorsig oor die ontstaan en doel van die Kairos-dokument gee:

Die eerste keer wat die saak van die Kairos-dokument na die oppervlakte kom is in Junie 1985 as 'n aantal teoloë begin vergaderings hou. Op 13 September 1985 is die geskrif gereed en op 25 September word dit aan die pers beskikbaar gestel. Die opstellers was 'n groep van 45 teoloë waaronder prof. dr. Charles Villa Vicencio van die Metodiste Kerk en Vader Albert Nolan van die Roomse Kerk in samewerking met die Institute for Contextual Theology wat vanuit die SA Raad van Kerke geînisieer is. Hierdie manne word ook genoem "The Kairos Theologians" en wil anoniem bly. 'n Waas van geheimsinnigheid hang oor wie werklik die skrywers is, maar agter hulle staan weer die SARK waarvan aartsbiskop Desmond Tutu vroeër en dr. Beyers Naude nou die algemene sekretaris is. Onder andere is daar met die eerste oogopslag 31 ondertekenaars van die Anglikaanse Kerk, 25 van die NG Kerk-familie, 23 Roomse en 20 Metodiste. Ook prof. J. W. de Gruchy wat nogal deur sommige as 'n "calvinis" aangeslaan word, het geteken. Ook dr. Beyers Naude, ds. Nico Smith en prof. W. Saayman (Unisa).

By die beskikbaarstelling aan die pers het dr. Banganjola voorwaardes aan die staat voorgehou, o.a. vrylating van alle politieke gevangenes, toelating van verbode politieke organisasies, skietstilstand met die staat se opponente en 'n onderhandelingsproses ${ }^{5}$ ).

Twee dinge is baie opvallend: Die voorwaardes by die Kairosvrystelling is feitlik dieselfde as die uitsprake van die Nasionale Inisiatief vir Versoening (NIV) wat ook in hierdie tyd van die jaar 
in Pietermaritzburg geloods is en dat dit juis van die ondertekenaars van die Kairos-dokument is wat betrokke is by hierdie inisiatief wat op kerklike gebied landswyd uitkring (ook onder lidmate w.o. geleerdes en predikante van die drie Afrikaanse Kerke).

Met ontploffende krag is die Kairos-dokument in Europa en in Suid-Afrika versprei. Die 32 bladsye is in Londen gepubliseer in Engels en spoedig is Europa ook oorstroom met vertalings in Duits, Frans en Hollands.

In Suid-Afrika is behalwe die oorspronklike teks in Engels, ook tienduisende opsommings in Zoeloe, Xhosa, Sotho en Afrikaans onder alle bevolkingsgroepe versprei ${ }^{6}$ ).

Daar is ook 'n sogenaamde "Kairos-brief" wat wyd op kerklike terrein onder alle bevolkingsgroepe versprei word. Dit is onderteken deur Mike van Graan die sekretaris; dieselfde man wat gedurende 1985 onder beskerming van die "Theological Exchange Programme" Latyns-Amerika besoek het om eerstehandse kennis oor die Bevrydingsteologie op te doen.

Die aanslag met die Kairos-dokument op die jeug is intens. In Januarie 1986 het die Kairos-Jeugkomitee in Johannesburg ontstaan. O.a. is die volgende Jeugorganisasies betrek: Catholic Youth, Wits Interchurch Youth, Sacc-Youth Desk, Student Union for Christian Action en Young Christian Students.

En met die Kairos-dokument word die aksie in die kerke fase na fase geloods. Die uur het gekom - so sê hulle. Die tyd is daar. Kairos!

\section{Verwerp die Kairos-dokument, dan verwerp jy Christus self!}

Vader Albert Nolan, die Roomse teoloog en een van die opstellers van die dokument, stel 'n radikale appél: Iemand wat hierdie Kairosdokument verwerp, verwerp Christus self!?').

Soos wat die Roomse Kerk aan sy dogma dieselfde gesag as die Bybel gee, so kom hier iets soos 'n onverbiddellike "dekreet".

Ons sien die sterkste "teologiese" dwang. Ons ervaar "kanonieke" intimidasie. Ons hoor van die grofste gewetensbinding. Ons verneem iets van die fanatieke "heilige oorlog" van die Islam.

\section{Marxisme 'n model vir die teologie?}

Een van die ondertekenaars, nl. eerw. Buti Thlagale, 'n Roomse priester in die bisdom van Johannesburg, verklaar prontuit:

"It is true, a lot of it has been gleaned from Marxist thought; we should'nt be trying to avoid that criticism"s).

En as daar dan met hierdie selferkenning van een van die ondertekenaars baie oorgeneem is van die Marxisme, hoe lyk dan nou die soort "teologie" van die Kairos-dokument?

Ons kan begin praat van 'n marxistiese "teologie" of anders gestel: Die Marxisme as ideologie kom in die gewaad van 'n christe. like "teologie".

Ons kan dit ook so sien dat die model van die Marxisme oorgeneem word om dan 'n "teologiese" inhoud daaraan te gee. En so beland ons meteens in die vaarwaters van die Neo-marxisme soos wat o.a. deur die Duits-Amerikaanse filosoof Marcuse geleer word. 
Hierop kom ons later terug.

Eers moet ons enkele marxistiese beginsels waarop die Kairosdokument gebou is identifiseer.

\section{Die "Kairos-idee" van Karl Marx}

Dit is byna ongelooflik en tog so verrassend profeties: Reeds 30 jaar gelede (1957) het die groot teoloog-filosoof S.U. Zuidema in 'n indringende studie oor die Kommunisme die "Kairos-idee" as een van die grondlyne van hierdie stelsel onderskei. Hy haal Karl Marx in sy "Manifes" aan waar hy gesê het: "Die wapens waarmee die "bourgeosie' (= die heersersklas) die feodalisme (= die leenstelsel deur die heersers) teen die grond geslaan het, word nou teen die 'bourgeosie' self gerig" (ondersitreping deur Marx self).

Hierdie woorde uit die marxistiese manifes - so sê Zuidema vertel duidelik van die Kairos-besef by Karl Marx. Hier is nou dic nuwe tyd wat aangebreek het. Hier is nou die keerpunt in die geskiedenis ${ }^{9}$.

Maar ook Lenin, die praktiese uitvoerder van Marx se filosofie, werk intensief met die "Kairos-idee" (hoewel hy en Marx die woord nooit gebruik het nie). Die voorhoede van die proletariaat (die werkersklas) moet "op " $n$ bepaalde moment" hulle rol speel om die land "ryp" te maak vir die revolusie ${ }^{(0)}$.

Dwarsdeur Marx se geskrifte sien ons die aanbreking van die groot moment: Die tyd vir die groot omwenteling is op hande! Die geskiedenis maak plek vir die geweldige hede vanwaar die eintlike geskiedenis dan sal begin. Die tyd is naby. Dit is die Kairos!'1).

\section{Die radikale verdeling in twee klasse}

Een van die mees tipiese grondbeginsels van die Marxisme is die verdeling van die mense in twee klasse, nl. die "Bourgeoisie" (die regerende klas) en die proletariaat (die onderste laag van die samelewing).

En die stryd is 'n voortdurende konflik tussen die onderdrukkers en die onderdruktes.

Van die begin af word hierdie marxistiese skema in die Kairosdokument geïmplimenteer as alreeds op die eerste bladsy gepraat word van die "conflict between different social forces" en "when we also come to see that the conflict in South Africa is between the oppressor and the oppressed, the crisis for the Church as an institution becomes much more acute. Both oppressor and oppressed claim loyalty to the same Church" (my onderstreping).

Hierdie marxistiese grondbeginsel is dan ook die fondament waarop die hele Kairos-dokument verder gebou word: die klassestryd tussen onderdrukker en onderdrukte.

Die klassestryd word dan die finale uitgangspunt om 'n radikale skeiding tussen verskillend soorte "teologie" te maak:

"The Church is divided and its day of judgment has come" ( $p$. 2). Die oordeelsdag vir die kerk het aangebreek!

Dit word volgens die Kairos-dokument nie volgens die Bybel deur die Raad van God bepaal nie (teologies!), maar deur die aardse model van die klassestryd. 
En dit is hierdie aardse "kairos", hierdie dag van oordeel, hierdie "moment of truth" in die konflik tussen onderdrukker en onderdrukte wat - so sê die ondertekenaars - ons gedwing het ("has compelled us") om die verskillende soorte "teologie" te onderskei (p. 2).

\section{Twee klasse - Twee gode}

Wat is die enigste grondslag vir 'n ware, suiwer teologie?

Elke Skrifgelowige, elke christen wat alleen buig voor die gesag van die Bybel en die Bybel aanvaar as die openbaring van God, as die enigste bron om God te ken (letterlik die "Theos" en "logos"), kan onmoontlik 'n "teologie" vanuit 'n buite-Bybelse ideologie opbou.

En dit is presies wat die manne van die Kairos dokument probeer doen: Omdat daar twee klasse is (onderdrukkers en onderdruktes) is daar ook twee gode, die god van onderdrukker en die god van die onderdrukte.

Klasseverskil gee nou kennis oor God = teologie.

Marxisme word die platform waarvan "teologie" geloods word.

Daar word gewerk met "die god van die staat". "Dit is 'n afgod. Dit is 'n god van die geweer, 'n god van onderdrukking. Inderdaad is dit die duiwel onder die dekmantel van 'n god - die Antichris wat verkondig word"12).

Daar word ook gewerk met die god van die witmense, "a god who is historically on the side of the white settlers, who disposses black people of their land..." (p. 7). Die witmense se god "is the god of superior weapons... "It is the god of casspirs and hippos, the god of teargas, rubber bullets, sjamboks, prison cells and death sentences" (p. 7).

\section{Die volgende Marxistiese stap: revolusie!}

As met die skema van Marx van onderdrukker en onderdrukte gewerk word en dit dan "teologies" toegepas word op die skema "god van die onderdrukker" teenoor "god van die onderdrukte", dan kom die volgende stap van die Marxisme: Revolusie!

Radikale afbreking van die bestaande strukture!

Dit kan alleen van onder af!

"Teologies" so sê die geskrif, werk God alleen van onder af en nie van bo af nie: "True justice, God's justice, demands a radical change of structures. This can only come from below, from the oppressend themselves. God will bring about change through the oppressed as he did through the oppressed Hebrew slaves in Egypt. God does not bring his justice through reforms by the Pharaoh's of this world" (p. 11).

\section{Staatspresident $P$. W. Botha die Farao van Suid-Afrika?}

Met sy manier om "teologies" te werk is die Kairos-dokument ook subtiel. Eers (bl. 10) word staatspresident P. W. Botha met sy "reforms" in die konteks van die onderdrukker geplaas, "people who are at the top of the pile", die wittes wat veranderinge van bo-af wil bring (lees die tweede laaste paragraaf op bladsy 10).

Op die volgende bladsy word met afwysing van hierdie "re- 
forms" dan die volgende "teologiese" stap gedoen deur na die Bybel te gaan: Van die oppressor (by implikasie P. W. Botha met sy "reforms") word oorgegaan tot "reforms by the Pharaoh's" (p. 11).

Subtiel, want 'n mens sal moeilik in 'n hof kan bewys dat die Kairos-dokument gesê het: Staatspresident P. W. Botha is die Farao van Suid-Afrika! Die suggestie is egter "teologies" geplant!

\section{Die Marxistiese skema van twee soorte geweld}

"Deze revolutionaire machtdaad kan tweërlei karakter vertonen. Zij kan nl. illegaal en legaal zijn". So ontleed Zuidema die kenner van die Kommunisme die marxistiese opvatting van geweld ${ }^{13}$ ).

Die onderdrukker se geweld is "illegaal", onwettig.

Die onderdrukte se geweld is "legaal", wettig.

In die hantering van geweld deur die proletariaat word Lenin die praktiese uitvoerder van die Russiese revolusie die "mensliewen. de geweldenaar". Lenin kan "enkel als geweldenaar mensliewend" wees ${ }^{14}$ ). "In Lenin komt de partij, in de partij komen de arbeiders, in de arbeiders komt heel het volk en in het volk heel de mensheid tot macht"15).

In marxistiese kringe word daar ook gepraat van "strukturele geweld" of "sisteem geweld" wat deur die onderdrukker gebruik word.

En nou sien ons waarom die Kairos-dokument praat van "structural, violence" (p. 11).

Die Neo-marxis Herbert Marcuse (Duits-Amerikaanse filosoof) probeer om revolusionêre geweld as 'n morele plig te regverdig:

"In the fight for freedom, in the interest of the whole against the particular interests of oppression, terror may become a necessity and an obligation. Here, violence, revolutionary violence, appears not only as a political means but as a moral duty. The terror is defined as counterviolence: It is "legitimate' in defense against the oppressors and untill they are defeated. Similarly, the Marxian concept of proletarian dictatorship is that of a transitional self-cancelling dictatorship"16).

In die marxistiese sisteem word geweld deur die onderdrukte aldus goedgepraat. Dit is "legaal", wettig, "a moral duty".

Hoor nou wat sê die 156 ondertekenaars van die Kairos-doku ment: "The State and the media have chosen to call violence what some people do in the townships as they struggle for their liberation, i.e. throwing stones, burning cars and buildings and sometimes killing collaborators" (p. 11).

Dit is volgens hierdie kerkleiers w.o. dr. Beyers Naude en dr. Nico Smit, nie geweld nie.

'n Christelike teologie?

Die evangeliese boodskap van Jesus Christus?

Is dit die "Uitdaging van die kerk" die "Teologiese Kommentaar" van die Kairos-dokument met hierdie "kerkleiers"?:

- om moorde op gemeenskapsleiers goed te praat...

- om brandende motorbande ("necklaces") om onskuldige mense vas te maak... 
- om skole waar kinders onderwys ontvang af te brand...

- om onskuldige mense in hulle motors met klippe te probeer doodgooi ...?

Is dit nou die "teologie" wat die Bybel leer?

Die kerk se taak? "Challenge to the church?

Die "mensliewende" geweldenaar Lenin het gesê:

"Die mees vrugbare grond waar ons die Marxisme moet saai is deur die godsdienstige sektor, want dit is die godsdienstige man wat die maklikste om die bos gelei word. Hy sal omtrent alles aanvaar as dit in godsdienstige terme verpak is"'17).

Die Kairos-dokument doen dit: Pak geweld in die sagte watte van "teologiese" terme en christelike woorde en gooi so 'n bietjie Bybelse sous daaroor en dan word dit "a moral duty"; die kerk moet dit steun!

Maar wat die staat doen, dit is geweld, "the structural, institutional and unrepentent violence of the State and especially the oppressive and naked violence of the police and the army" (p. 11 en 12).

\section{"Daar is nie "n christelike oplossing nie"!}

Vir die politieke krisis in Suid-Afrika verklaar die "teoloë" van die Kairos-dokument: "There is no specifically Christian solution" (p. 14). Vir hulle is daar alleen 'n politieke oplossing: "Changing the structures of society is fundamentally a matter of politics" (p. 13).

\section{Romeine 13 Marxisties verklaar}

Die Bybelse grondslag van die gesag van die staatsowerheid is Romeine 13. Die owerheid (selfs die heidense Romeinse owerheid in die tyd van Paulus) "dra die swaard nie verniet nie, want hy is 'n dienaar van God, 'n wreker om die wat kwaad doen te straf" (Rom. $13: 4)$.

Maar hoe lyk dit as die Kairos-dokument Romeine 13 verklaar?

Die volgende word gesê: "Die Staat maak beroep (nie goele Afrikaans nie - V.E. d'A) op Romeine 13:1-7 waar Paulus sê dat ons gehoorsaam moet wees aan die staat. Dit sou waar wees onder normale omstandighede, maar Paulus sê niks in hierdie teks omtrent wat ons moet doen as die staat onregverdig, onderdrukkend en tiranniek word nie" (Afr. opsomming).

nie" (Afr. opsomming).

Dit is uiters onwetenskaplik en uiters nailef om te beweer dat die Romeinse owerheid in die tyd van Paulus nie "onderdrukkend en tiranniek" was nie. Alleen totaal oningeligte kerkmense sal soiets aanvaar.

Of is hierdie teoloë van die Kairos-dokument heeltemal onkundig oor die feit dat die wrede keiser Nero, die aarts-christenvervolger tydens die ontstaan van die Romeinebrief in die jaar 58 aan bewind was?

Die soort teologie wat hier na vore kom, is die "Relatiwiteitsteologie" nl. dat Rom. 13 nie 'n algemene beginsel vir gehoorsaamheid 
aan die staat gee nie, maar slegs vir daardie tyd van Paulus in sy omstandigheid gegeld het. uitleg.

Alleen die situasie hier en nou bepaal die beginsel van Skrif-

Dit is die marxistiese begrip dat "die omgewing die mense vorm" wat dan verhef word as ' $\mathrm{n}$ beginsel om van daaruit die Bybel te verklaar ${ }^{18}$ ).

Aan die begin van die Kairos-dokument word opsetlik afgereken met Romeine 13 .

Dit is nie so dat God gesê het dat 'n mens aan die owerheid gehoorsaam moet wees nie!

Aan die einde kom die Kairos-dokument se bevel: Julle moet

die owerheid ongehoorsaam wees!

Nou het die "teoloog" 'n revolusionêr geword.

"The Church should not only pray for a change of government, it should also mobilise its members in every parish to begin to think and work and plan for a change of government in South Africa... the Church will have to be involved at times in civil disobedience" (p. 24).

Stel jou voor dat die kerk so 'n dokument in Rusland sou publiseer. Of dat die kerkmense dit hier in SA sou doen nadat die Marxiste werklik die staat oorgeneem het?

\section{Watter soort "teologie"?}

Die ondertekenaars van die Kairos-dokument is nie beskeic oor wat volgens hulle die regte soort teologie moet wees nie. In hoofstuk 4 noem hulle dit die "profetiese Teologie".

1. Ten eerste 'n "sosiale ontleding" ("social analysis")

Ons haal aan uit die Afrikaanse opsomming: Hierdie teologie "sal moet gebaseer word op 'n deeglike insig in die tekens van ons tyd, dit wil sê 'n sosiale ontleding van die teenstrydige magte of belange wat deel uitmaak van ons toestand van onderdrukking".

"Daarna sal ons moet teruggaan na die Bybel...

En skielik, midde in hierdie verwysing na die Bybel (nog voordat die "sosiale ontleding" gemaak is, d.w.s. nog voordat daar enige "teologiese" resultate is) kom die radikale klasseverde!ing van Karl Marx tussen onderdrukker en onderdrukte na vore.

Nee, geen rasseverdeling nie, maar klasseverdeling: "It would be quite wrong to see the present conflict as simply a racial war. The racial component is there but we are not dealing with two equal races or nations each with their own selfish group interests. The situation we are dealing with is one of oppression. The conflict is between an oppressor and the oppressed. The con flict is between two irreconcilable causes or interests in which the one is just and the other is injust" (p. 15).

Weer eens, die uitgangspunt is marxisties: twee klasse, onderdruklkers en onderdruktes - en hulle is in stryd met mekaar (klassestryd).

2. Onderdrukking as ' $n$ basis vir teologie

Dit is 'ogies dat as 'n teoloog met die model van Marx (onderdruls- 
ker - onderdrukte) na die Bybel gaan, hy dan ook die Bybel deur hierdie bril gaan lees.

Dit word dan die Kairos-dokument se tweede vereiste vir 'n "profetiese teologie", onderdrukking in die Bybel. "Oppression is a central theme that runs right through the Old and New Testaments". 'n Skrywer word ook aangehaal wat gesê het dat onderdrukking "a basic structural category of biblical theology" isi (p. 16).

Hier het ons niks anders as 'n eensydige, tendensieuse soort teologie vanuit die Marxisme nie.

Selfs Jesus Christus se sterwe dien hierdie aardse politieke doel as sy kruisdood nie meer versoening met God is nie en dat Hy die Middelaar tussen God en mens is nie en dat $\mathrm{Hy}$ vir die mens as Borg deur God gestraf is nie, maar alleen 'n soort horisontale plat "teologie" dat hy die slagoffer van onderdrukking en geweld was (p. 17).

Was God, wat Sy Seun gestraf het dan ook hierdie onderdrukker?

3. Met Karl Marx na die kerkgeskiedenis

Die derde beginsel vir 'n sogenaamde "profetiese teologie" deur die Kairos-mense, is om na die "Christelike tradisie" te gaan en onderdrukking as "tirannie" te brandmerk.

Ook hier het ons geensins met "teologie" te doen nie, maar dit is ' $n$ blatante pleidooi om van die huidige regering in die RSA ontslae te raak. Selfs in die Afrikaanse opsomming wat "sagter" as die oorspronklike Engelse dokument is, word die revolusie en omverwerping van die huidige regering sonder enige twyfel gestel: Die huidige bewind is "moreel gesproke, 'n onwettige bewind en behoort deur 'n regering wat namens die hele bevolking, die gemenebes, sal regeer vervang word".

4. Die ware hoop - God is aan die kant van die onderdrukte

Vir die soveelste keer is dit die model van Marx wat die teologie moet bepaal. Ook die christelike hoop word vereng tot die klein keurslyf van die klassestryd - hoop vir die onderdrukte.

Hier vind ons ook 'n duidelike invloed van Moltman se teologie van hoop. Daar moet altyd 'n hoop wees dat die bevryding sal kom en dit is die kerk se taak om hierdie hoop lewendig te hou. "Hope needs to be maintained and strengthened. Hope needs to be spread. The people need to hear it said again and again that God is with them (p. 21).

Hierdie hoop gaan egter langs 'n pad van pyn. Die stryd moet egter in die maande en jare wat kom verskerp word omdat daar geen ander manier is om die ongeregtigheid te verwyder nie. Maar God is met ons! Hy is aan die kant van die onderdrukte. Dit is die refrein oor-en-oor.

In Hoofstuk 5 volg 'n program van aksie vir die kerk. Dit word genoem "Challenge to Action". Dit bestaan uit 6 sake:

1. God is aam die kant van die onderdruktes.

Kerkeenheid is alleen moontlik as alle kerke hulle skaar aan die kant van die onderdruktes. 
2. Deelname in die stryd.

"Christians... must quite simply participate in the struggle for liberation and for a just society". Dit is die eintlike taak van die kerk.

3. Alle kerklike aktiwiteite moet ' $n$ ander vormi kry.

Die Kairos-dokument noem dit "Transforming Church Activities". Die dienste op Sondag, die Nagmaalsdienste, doopplegtighede, Son dagskool, begrafnisse ens. moet alles aangepas word by die bevrydingstryd. Dit moet alles gebruik word "to further the liberating mission of God and the Church in the world" (p. 23).

4. Spesiale veldtogte ("Special Campaigns).

Die kerk moet spesiale saamtrekke loods om die bevrydingstryd in Suid-Afrika te bespoedig.

5. Burgerlike ongehoorsaamheid.

Die kerk moet nie net bid vir die val van die regering nie, maar die kerk moet ook sy lidmate mobiliseer tot burgerlike ongehoorsaamheid ("civil disobedience") aan die staat (p. 24).

6. Morele leiding aan die mense.

Dit is die kerk wat die boodskap van bevryding nie alleen in woorde moet preek nie, maar ook deur aksies, dade, projekte, veldtogte ens.

\section{Kairos: 'n nuwe "evangelie" volgens die Marxisme}

In die Kairos-dokument is daar geen sprake van 'n teologie wat vanuit die Bybel uitgebou word en in die praktiese lewe toegepas word nie. Dit is gewortel in die Marxisme en probeer die Bybel daarby aanpas. Die Duitse teoloog Paul-Gerhard Kauffenstein het dit raak geformuleer: "Die KAIROS-Theologie ist die pseudochristliche Komponente zur antichristlichen Diesseitreligion des Kommunismus"19). Vry vertaal: Die Kairos-teologie is die vals-christelike samevatting tot ' $n$ antichristelike aardse godsdiens van die Kommunisme.

Opmerklik is dit dan ook dat die dokument homself deeglik probeer verskans teen 'n moontlike kritiek dat dit kommunisties is. Dit doen hy drasties in hoofstuk 2. 3.

In feite word met die Kairos-dokument 'n nuwe soort godsdiens vir Suid-Afrika aangekondig — 'n Marxistiese christendom.

Dit is 'n geseklariseerde (verwêreldlikte) godsdiens, gebou op die marxistiese sisteem. logie".

Dit is ' $n$ on Bybelse ideologie onder die dekmantel van 'n "teo-

Dit is die sogenaamde teologie van Revolusie en Bevryding wat prakties toegepas word.

Die teoretiese prediking van politieke bevryding word nou in revolusionêre dade via die kerk omgesit.

Hier is vir Suid-Afrika (in Latyns-Amerika het dit alreeds gebeur) 'n nuwe godsdienstigheid, 'n nuwe heilsverwagting, 'n nuwe geloof , 'n nuwe toekoms.

Alles is uit, deur en tot die mens. Van die "Soli Deo Gloria" (aan God alleen die eer) het niks meer oorgebly nie. 
Hier kom die nuwe godsdienstige proletariaat op mars deur die kerk.

Hier maak dit nie saak dat jy staan en preek onder die banier van die hamer en die sekel nie.

Die heilstyd (kairos) moet nou oorgaan tot die heilsdaad vir die politiek.

Die kerk (die liggaam van Christus) word vervang met die poli tieke organisasie.

Die evangeliese preek word 'n politieke manifes - vir die marxis.

Die preekstoel van die Bybelse boodskap, word 'n politieke kateder - vir die marxistiese ideologie.

\section{En ons? - hulle wat die Marxisme verwerp}

Hoe verder 'n mens hierdie Kairos-dokument lees, hoe meer besef jy die verskriklike dinamiese mag en $\mathrm{krag}$ van die diaboliese antichristelike Marxisme. Dit is veel erger en verskrikliker as Marx se "Das Kapital" of sy "Manifesto" of die geskrifte van Lenin, juis as dit die Bybel wil inspan voor sy aardse koninkryk. En ook juis as die kerk geëksploiteer word as 'n politieke organisasie - ons haal aan - "to determine an appropriate form for action, depending on their particular situation, and to take up the action with other related groups and organisations" (p. 24).

Vir die kerk van Jesus Christus is dit later as wat ons besef. Dit is die een groot waarheidsmoment waartoe hierdie marxistiese dokument in die gewaad van teologie ons bring. Dit is die harde feit dat die messias van bevryding vanuit die aarde, vanuit die situasie, vanuit die konkrete werklike revolusie duidelik voor ons staan ( 2 Thess. 2). Dit is ons Kairos! Laat ons daaroor nie twyfel nie. Dit is die uur van skeiding in die teologie: of die ware kennis van God alleen uit Sy Woord, die "sola Scriptura" óf die valse profeet met sy ideologie.

"Want die tyd is daar dat die oordeel moet begin by die huis van God" (1 Pet. 4:17). Die oorspronklike Griekse woord vir "oordeel" is ook skeiding. En moenie skrik nie: Hierdie skeiding is besig om voltrek te word binne ons Afrikaanse - en ook ander kerke - selfs binne ons gereformeerde teologie.

Wat bly oor?

As ons maar God se Woord in sy volle gesag, in sy volle beloftes en sy ewige krag bewaar!

Ad fontes! Terug na die fontein!

Terug na ons gereformeerde belydenis wat hierdie Woord bo alle twyfel bely as die ewige gesagvolle volmaakte Woord.

"Omdat jy die woord van My lydsaamheid bewaar het, sal Ek jou ook bewaar in die uur van beproewing wat oor die hele wêreld kom om die bewoners van die aarde op die proef te stel" (Openb. $3: 10)$. 


\section{Literatuur:}

Behalwe waar anders vermeld, gebruik ek deurgaans die volledige Engelse teks en gee by aanhalings die bladsye in hakies. Die volledige titel van hierdie teks is: The Kairos Document, 3rd Impression: November 1985. Braamfontein: The Kairos Theologians.

1. Die Kairos Dokument (Afrikaanse opsomming) 1985. Braamfontein: The Kairos Theologians.

2. Pop, F. J. 1957. Bijbelse Woorden en hun Geheim, I. 's-Gravenhage: Boekencentrum N. V.

3. Kairos Dokument (Afr. opsomming).

4. The Shorter Oxford English Dictionary. 1962. Londen: Encyclopaedia Brittannica Ltd.

5. Beeld 26 Sept. 1985, The Star 26 Sept. 1985, The Citizen Sept. 1985.

6. The Kairos Document, 3rd Impression: November 1985. Braamfontein: The Kairos Theologians.

7. Signposts, vol. 1, nr. 1. 1986.

8. Nuusbrief van die Roomse Kerk se "Diocesan Interim of Justice and Reconciliation", Signposts: 2.

9. Zuidema, Dr. S. U. 1957. Communisme in Ontbinding, p. 81. Wageningen. N. V. Gebr. Zomer \& Keunings Uitgeversmaatchappij.

10. Jongeling, P. 1971. Het vlammend Schrift, p. 202. Franeker: T. Wever.

11. Zuidema a.w., p. 81 .

12. Kairos Dokument (Afr. opsomming).

13. Zuidema, a.w. p. 134

14. Zuidema, a.w. p. 136.

15. Zuidema, a.w. p. 136

16. Marcuse, Herbert, Ethics and Revolution, 'n Artikel in De George, Richard T. 1968. Ethics and Society, p. 137. Londen: Macmillan.

17. Christian Mission International. 1986. When God is replaced p. 3. Primrose Hill $\mathbf{S} . \mathbf{A}$.

18. Kauffenstein, P. G. 1986. Kairos, p. 9. Kenmare: Protest Informationdienst.

19. Kauffenstein, a.w. p. 29. 